\title{
Comentario al artículo "Control de convencionalidad interamericano: una mera aplicación del derecho internacional"*, de Karlos A. Castilla Juárez ${ }^{* *}$
}

Bienvenidas las revisiones académicas de la jurisprudencia de la Corte Interamericana de Derechos Humanos, sobre todo las que afirman ser críticas, pues demuestran interés en las construcciones jurídicas elaboradas por el organismo internacional; y, parafraseando a Dalí (que a su vez al parecer parafraseaba a WILDE), lo importante es que hablen de ti, aunque sea mal, de manera que este tipo de trabajos demuestra el creciente interés que despierta el organismo internacional en la academia. Adicionalmente, estoy convencido de que solo a partir de la revisión y el debate académico pueden los tribunales afinar su jurisprudencia.

Hecha esta reflexión paso a hacer algunas acotaciones sobre el artículo que me corresponde comentar, en el cual se hace una virulenta crítica del concepto de control de convencionalidad empleado por la jurisprudencia de la Corte Interamericana de Derechos Humanos. Si no me equivoco, la malquerencia del autor reposa sobre todo en dos falencias de las que pretendidamente adolece esta figura, aunque también se hace alusión a algunas otras. Por un lado, la falta de precisión conceptual de la Corte Interamericana en torno al concepto de control de convencionalidad; en pocas palabras, ¿de qué habla la Corte cuando habla de control de convencionalidad? (pido excusas por este guiño literario a CARVER). Por otra parte, lo poco apropiado del término para referirse a la idea que pretende representar.

* Artículo publicado en la Revista Derecho del Estado n. $^{\circ} 33$, Universidad Externado de Colombia, julio-diciembre de 2014, pp. 149-172.

** Para citar el artículo: A. Julio Estrada. Comentario al artículo "Control de convencionalidad interamericano: una mera aplicación del derecho internacional", de KARLOS A. CASTILLA Jú́rez. Revista Derecho del Estado n. ${ }^{\circ} 34$, Universidad Externado de Colombia, enero-junio de 2015, pp. 51-54. DOI: 10.18601/01229893.n34.02

*** Abogado de la Universidad Externado de Colombia, doctor en Derecho por la Universidad Complutense de Madrid, docente-investigador del Departamento de Derecho Constitucional de la Universidad Externado de Colombia. Ex magistrado (e) de la Corte Constitucional colombiana. Director jurídico de la Corte Interamericana de Derechos Humanos. Contacto: alexei. julio@uexternado.edu.co Recibido el 12 de febrero de 2015, aprobado el 19 de marzo de 2015. 
Ahora bien, comparto parcialmente la primera crítica, pero disiento sustancialmente de la segunda, o tal vez de la forma como está expresada. Paso a explicar mi posición. Como reseña con acierto el autor, el concepto de control de convencionalidad no ha sido empleado de manera unívoca desde su enunciación por primera vez en el año 2006. Sin embargo, esta aparente falta de rigor, a mi juicio, es excusable. Sería exigir demasiado pretender que desde su primera decisión el organismo internacional propusiera un concepto definitivo (y en esa medida invariable e inmodificable) de lo que ha de entenderse por control de convencionalidad. Cabe recordar que las construcciones jurisprudenciales por regla general son evolutivas y se van enriqueciendo y modificando a lo largo de los casos y de los años. Y aunque el autor no parece creerlo, las transformaciones y precisiones que se han incorporado al concepto sí guardan relación con los distintos marcos fácticos que ha resuelto la Corte Interamericana. Tal vez lo que subyace en este reclamo es una particular visión de la tarea de creación del derecho por parte de los tribunales -incluso los internacionales-, que sin duda tiene que ver con ciertas dificultades para aproximarse a la jurisprudencia utilizando las técnicas del análisis del precedente y de la casuistry propia de los sistemas de common law.

Así por ejemplo, las diferencias en torno al sujeto obligado a realizar el control de convencionalidad se explican en virtud del contexto fáctico de cada caso. En efecto, en Almonacid Arellano y otros se afirma que el control de convencionalidad corresponde al "Poder Judicial" porque el pronunciamiento se refiere a una violación grave de derechos humanos y a la aplicación, por parte de los tribunales, de una ley de amnistía mediante la cual se dispuso el cese inmediato de las investigaciones y el archivo del expediente del caso a nivel interno. Mientras que en Vélez Loor, en cuanto al sujeto obligado, se hace referencia a "los órganos de cualquiera de los poderes cuyas autoridades ejerzan funciones jurisdiccionales" ${ }^{1}$, porque el caso tiene que ver con la obligación de observar las garantías del debido proceso por parte de la autoridad administrativa autorizada por la ley para ejercer funciones jurisdiccionales en un proceso migratorio. Por su parte, en Cabrera García y Montiel Flores (de 2010) se precisa que el sujeto obligado son "los jueces y órganos vinculados a la administración de justicia en todos los niveles" 2 , pues se examinaba la declinación de la competencia del Ministerio Público Federal al Ministerio Público Militar para continuar con las investigaciones del caso a nivel interno, con lo cual terminaron siendo

1 Corteidh. Caso Vélez Loor vs. Panamá. Excepciones Preliminares, Fondo, Reparaciones y Costas. Sentencia de 23 de noviembre de 2010. Serie C n. ${ }^{\circ} 218$, párr. 287.

2 CorteidH. Caso Cabrera García y Montiel Flores vs. México. Excepción Preliminar, Fondo, Reparaciones y Costas. Sentencia de 26 de noviembre de 2010. Serie C n. ${ }^{\circ} 220$, párr. 225 . 
conocidos por el fuero castrense delitos que no tenían estricta relación con la disciplina militar o con bienes jurídicos propios del ámbito castrense. Y en Gelman se menciona que es "función y tarea de cualquier autoridad pública y no sólo del Poder Judicial"”, dado que el pronunciamiento se refiere a una violación grave de derechos humanos que no podía ser investigada debido a que había sido aprobada al respecto una ley de amnistía, así como en razón del respaldo dado por la ciudadanía a dicha ley en dos ocasiones, esto es, mediante un referéndum en 1989 y a través de un plebiscito en 2009; al igual que en razón de la vigencia y efectos de dicha ley en la investigación del caso a nivel interno. Es decir que diversos órganos estatales e incluso la voluntad popular habían participado en la violación.

A la luz de lo anterior se comprende que las complejidades del caso concreto sí explican la modificación del concepto. Así las cosas, la crítica que se podría plantear es la que se refiere a las dificultades e inconvenientes que implica que los tribunales pretendan hacer construcciones teóricas que luego se verán expuestas a los avatares de las circunstancias fácticas de los casos futuros; esta crítica se enmarcaría en el famoso debate entre maximalismo y minimalismo judicial.

Por otra parte, el autor sostiene que hay una falta de correspondencia entre el término control de convencionalidad y la idea que pretende representar. Pero formula esta crítica a partir de un símil que a mi juicio es desafortunado, por cuanto asemeja la figura al control de constitucionalidad. Para tales efectos el artículo en examen propone un concepto de control de constitucionalidad que es bastante controvertido doctrinalmente, porque asimila control de constitucionalidad a justicia constitucional. Es sabido que la justicia constitucional es solo una de las modalidades o vertientes del control constitucional, y que a lo largo de la historia se han ensayado diversas formas de control que no necesariamente recaen en los tribunales, e incluso los defensores del asî llamado constitucionalismo democrático sostienen la idea de que el control constitucional no debe corresponder exclusivamente a los tribunales; es decir, son parcialmente refractarios a la idea de la justicia constitucional.

Hechas las anteriores consideraciones, es claro que la crítica no puede basarse en la falta de correspondencia entre los términos control de convencionalidad y control de constitucionalidad, porque cualquier órgano estatal puede realizar control constitucional, no solamente el tribunal constitucional (equiparable a la Corte Interamericana de Derechos Humanos como único órgano competente para realizar control de convencionalidad). En esa medida habría que examinar con mayor detenimiento la idea que está detrás el concepto de control de convencionalidad como inaplicación de la normativa

3 Corteidh. Caso Gelman vs. Uruguay. Fondo y Reparaciones. Sentencia de 24 de febrero de 2011. Serie C n. ${ }^{\circ} 221$, párr. 239. 
interna que resulte contraria a la Convención y a la jurisprudencia de la Corte. Es decir, no se trata de una mera interpretación conforme de la legislación interna -como a veces parece sugerir el artículo en estudio-, sino de una verdadera decisión interpretativa de no aplicar el derecho interno y, en su lugar, aplicar una fuente a la que se reconoce una jerarquía superior. Desde esta perspectiva considero que es comprensible utilizar la expresión control de convencionalidad, por muy imperfecta que parezca. 